\title{
A Imagem Pública do Músico e da Música na Antigüidade Clássica: Desprezo ou Admiração?
}

Fábio Vergara Cerqueira*

\section{RESUMO:}

O objeto deste artigo será analisar o conjunto de representações que definem o músico no imaginário social das sociedades grega e romana antigas. Para tanto, buscaremos reconstituir a imagem pública que o homem antigo fazia dele. Essa imagem compunhase, veremos, de um cluster, algo coerente, algo contraditório, de noções, conceitos, valores e preconceitos.

Palavras-chave: Antigüidade Clássica, Músico greco-romano, Imagem Pública.

\section{I - Introdução}

O objeto deste artigo será analisar o conjunto de representações que definem o músico no imaginário social das sociedades grega e romana antigas. Para tanto, buscaremos reconstituir a imagem pública que o homem antigo fazia dele. Essa imagem compunha-se, veremos, de um cluster, algo coerente, algo contraditório, de noções, conceitos, valores e preconceitos.

Enquanto um estudo enquadrado na História das Mentalidades segue o conceito, no que se refere à temporalidade, da longue durée: lidamos aqui com elementos mentais, representações, da codificação imaginária de uma figura social específica, o músico, elementos cuja origem histórica não se limita a conjunturas históricas pontuais, cuja causalidade não se remete ao plano estritamente "acontecimental", contingente, mas refletem opiniões que se estruturaram ao longo dos séculos e que manifestam longa permanência, apesar de profundas mudanças sociais vividas pelas sociedades mediterrâneas antigas. Deste modo, abordamos de forma sincrônica, desde uma perspectiva antropológica comparativa, testemunhos de textos antigos que se dispersam por quase 12 séculos, de Homero a Santo Agostinho. 
Quando se pensava no músico como profissional, pensava-se ao mesmo tempo em outras dimensões da experiência cotidiana, das quais a música de certa forma participava. Assim, a forma como o músico era visto era contaminada pelos elementos mentais que conceituavam essas outras atividades sociais. É necessário, portanto, entendê-los, para se poder entender a opinião corrente sobre o músico. Além da relação que o músico mantinha com a própria música, em nosso estudo, pesquisamos a relação que este mantinha com algumas outras dimensões da experiência cotidiana, como aquela com o mundo do trabalho, do artesanato e da técnica, com o submundo dos vícios e da prostituição, e, finalmente, com a homossexualidade passiva, com a efeminação.

No presente texto, trataremos tão-somente de dois aspectos da composição da imagem do músico:

1) o descompasso entre o estatuto da música e do músico;

2) o estabelecimento da imagem do músico a partir da intersecção da condição deste com o mundo do trabalho.

Uma questão importante para se falar sobre a imagem do músico é colocar a diferenciação existente entre o que se entendia por músico profissional e por amador. Ora, quem era visto como músico profissional? Entre várias atividades que se caracterizavam por uma ocupação com a música, nem todas eram percebidas como profissão. Podemos aqui enumerar diversas atividades musicais. Temos o professor (de canto, de instrumento ou de teoria), o concertista (músico virtuose que participava das competições) e o compositor (que era também um poeta e com certeza executava suas músicas, como o famoso compositor cretense Mesomedes de Creta, músico oficial da corte de Adriano). Ou, num campo social distinto, as hetairai e pornai (contratadas para alegrar o ambiente sensual dos symposioi), bem como os jovens citaristas e cantores efeminados que atendiam aos prazeres sexuais de adultos pederastas. Os auletai que acompanhavam os sacrifícios religiosos, ou atividades laboriais, como a colheita de uva ou azeitonas, situavam-se no campo do proletariado musical.

Havia, ainda, o músico amador (o cidadão em geral, que na idade escolar, ao menos no período clássico grego, aprendia música para saber distinguir o belo) e o coralista amador (cuja participação nos corais marcava uma obrigação cívica da cidadania em muitas cidades gregas). Contrapondo-se a estes, surgiram os coralistas profissionais (que compunham as corporações ou sindicatos de músicos que apareceram na época helenística, exigindo uma elevada remuneração por seu trabalho 
especializado). Além desses, podemos enumerar os teóricos musicais (que exerciam também a função de professores) e o fabricante de instrumentos, como o aulopoios (cuja atividade manual o caracterizava como um banausos). Poderíamos ainda recordar vários outros, como o tocador de trombeta (salpinx), que anuncia os exércitos, ou o auletes, que dá o ritmo ao movimento das falanges hoplíticas; ou ainda o auletes ou tocador de castanholas (krotala) que acompanhavam os atores na apresentação de peças, bem como os próprios atores, que ao mesmo tempo eram cantores, e os $\chi 0 \rho \circ \delta 1 \delta \alpha \sigma \kappa \alpha \lambda$ or, que ensaiavam os coros e eram responsáveis pelo ensaio dos atores trágicos.

Dessas atividades supracitadas, algumas não eram vistas como profissionais e, portanto, não participavam diretamente da imagem do músico que estudaremos aqui: tanto o músico amador, seja ele cantor ou instrumentista, jovem aprendiz ou adulto diletante, como o teórico musical, não eram vistos como músicos profissionais, pois se dedicavam à música de uma forma digna a um homem livre, contrariamente àqueles que a exerciam como um trabalho do qual, servilmente, tiravam seu sustento. No curso de nossa análise, demonstraremos como essas diferentes atividades eram vistas no estabelecimento da imagem (ou das imagens) do músico em relação aos campos sociais da técnica, do trabalho e do artesanato.

\section{II - O descompasso entre o estatuto da música e do músico:}

A cultura grega clássica conferiu à música um lugar de destaque, definindo-a como formadora do caráter do cidadão, pois possibilitaria o aprendizado da virtude e o desenvolvimento espiritual (enquanto à ginástica caberia o desenvolvimento corporal). Por esses motivos, a tradição aristocrática das cidades gregas garantia o ensino musical como etapa básica da formação do jovem, exigindo deste alguns anos de dedicação ao estudo do canto e da lira. Essa valorização da música, porém, não acarretava uma valorização do músico profissional e da dedicação especializada à execução musical por parte de um cidadão adulto. Aristóteles não hesitava em chamar os músicos profissionais de vulgares e em definir a execução musical como imprópria a um homem livre. Para ele, os cidadãos deviam dedicar-se à execução musical somente em sua juventude, abandonando essa prática na idade adulta.

Desse modo, não havia correspondência entre o estatuto da música e o estatuto do músico: sendo a primeira enaltecida, o outro, por sua vez, era socialmente execrado. Ao contrário da beleza moral que a apreciação musical propiciava, dedicar-se à 
profissão de músico era considerado "labutar em tarefas medíocres e aplicar esforços em objetos inúteis". O músico profissional, portanto, "alardeia indiferença pela beleza moral" (Plutarco. Péricles, 2).

Numa passagem de Plutarco, encontramos uma comparação entre a música e a atividade artesanal e manufatureira, em que ele estabelecia um paralelismo na distinção entre o valor do produto e do produtor: enquanto o produto era valorizado, o trabalho do produtor era desprezado.

Em outros campos, podemos muito bem admirar o que se fez sem, necessariamente, querer fazer o mesmo.

Ao contrário, não é raro suceder que gozemos a obra ao mesmo tempo que desprezamos o autor. Tal é o caso dos perfumes e dos tecidos de púrpura: agradam-nos sim, mas consideramos os ofícios do tintureiro e do perfumista como servis e indignos de um homem livre. Bastante razão teve Antístenes ${ }^{1}$ quando respondeu a alguém que lhe afirmava ser Ismênias ${ }^{2}$ um excelente flautista: "Sim, mas como homem é uma nulidade, do contrário não tocaria tão bem". Da mesma forma Filipe ${ }^{3}$, dirigindo-se ao filho que, com muita graça e talento acabara de tocar cítara num banquete, perguntou-lhe: "Não tens vergonha de tocar com tanta habilidade?". Com efeito, basta a um rei ouvir o som da cítara quando dispõe de tempo para isso, e já presta grande homenagem às Musas ao assistir aos concursos onde outros disputam os prêmios.

Desse modo, havia uma coincidência nos critérios de julgamento das profissões de músico e artesão, pois ambas estavam submetidas à "ideologia da causa final". Segundo essa ideologia, "cada tarefa encontra-se definida em função do produto que visa a fabricar: a sapataria com relação ao calçado, a olaria com relação ao pote", e, sob o mesmo ponto de vista, a música com relação à melodia e nunca com relação ao músico. Vernant nos permite compreender como, nesse esquema de pensamento, o produtor - artesão ou músico - não era valorizado.

A teoria demiúrgica, cujo resultado é a "ideologia da causa final", submetia a obra do autor (músico ou artesão) à necessidade do usuário. Assim, segundo Vernant, "nesse sistema mental, o homem age quando utiliza as coisas e não quando as produz. $\mathrm{O}$ ideal do homem livre, do homem ativo, é ser universalmente usuário, nunca produtor". 6 Havia todo um esquema que colocava a ação fabricadora, a $\pi$ oın $\sigma \iota \varsigma$, o produtor, sob a dependência e o serviço pessoal do usuário.

A mesma teoria demiúrgica que regia o julgamento social dos músicos e artesãos entre os gregos, parecia valer entre os romanos. Para estes,

o verdadeiro autor de uma obra de arte não é quem a modelou, o verdadeiro artífice de um monumento não é quem o ergueu. É o personagem que o desejou e financiou, e quem impôs seu gosto e sua ideologia: o encomendador. ... Seja qual for seu talento, o artifex permanecerá sempre como o agente executor a serviço de um cliente. ${ }^{7}$ 
Graças à “ideologia da causa final”, o valor atribuído à música não era repassado à figura do músico, vista como torpe e vulgar. Na Atenas clássica, ter uma formação musical, ser um $\mu$ о $\sigma 1 \kappa о \varsigma \alpha \nu \eta \rho$, era sempre uma boa referência social, disso temos inúmeras provas, desde as evidências de que o próprio Platão fosse um músico amador ${ }^{8}$ e de que Sócrates conhecesse as regras da composição musical, ${ }^{9}$ até as insistentes desculpas de Temístocles quanto à sua incapacidade para tocar lira. ${ }^{10}$ No entanto, ser um músico destacado não era garantia de reconhecimento social, mesmo que todos concordassem em pagar bons salários aos virtuosi, que eventualmente podiam se tornar bastante ricos e afamados, como foi o caso de Ismênias de Tebas. Malgrado o desprezo do filósofo Antístenes, que o considerava uma nulidade como homem, Ismênias foi um dos auletai mais ricos e mais prestigiados da Antigüidade.

Desse modo, a distinção entre o valor da música e do músico ligava-se inexoravelmente ao sistema mental, baseado na teoria demiúrgica, que regulamentava a depreciação do trabalho manual e remunerado. De acordo com este sistema, o produtor era desprezado e o produto, submetido ao usuário, era valorizado, como instrumento ideológico para demarcar o assujeitamento de um grupo social a outro - daquele marcado pela servidão àquele presenteado pela liberdade.

Havia, porém, outro sistema que participava do balizamento que separava música e músico, pondo-os em extremos opostos da escala de valores sociais. Tratavase do sistema de valores que demarcava os campos das atividades intelectuais, de forma correlata àquele que ordenava o universo das profissões, definindo o estudo que era considerado digno de um homem livre e o que caracterizava uma condição servil.

Existia, conforme esse sistema, um conjunto de atividades intelectuais que dignificariam o espírito do homem livre e outras que o tornariam servil, bruto. Desse modo, de um lado, temos as ocupações "liberais", adequadas ao homem livre, que visavam estritamente ao prazer do espírito e ao seu aperfeiçoamento; de outro, temos as práticas, manuais, que piorariam as condições do corpo. Assim, Aristóteles tomava em consideração o corte epistemológico e moral entre conhecimentos "liberais" e "práticos" para estabelecer seu modelo pedagógico, determinando quais os aprendizados que deviam ser ministrados aos jovens:

Não é difícil de ver, então, que devem ser ensinados aos jovens os conhecimentos úteis realmente indispensáveis, mas é óbvio que não se lhes deve ensinar todos eles, distinguindo-se as atividades liberais das servis; deve-se transmitir aos jovens, então, apenas os conhecimentos úteis que não tornam vulgares as pessoas que os adquirem. Uma atividade, tanto quanto uma ciência ou arte, deve ser considerada vulgar se seu conhecimento torna o corpo, a alma ou o intelecto de um homem livre inúteis para a posse e a prática das qualidades morais. Eis porque 
chamamos vulgares todas as artes que pioram as condições naturais do corpo, e as atividades pelas quais se recebem salários; elas absorvem e degradam o espírito. ${ }^{11}$

Segundo Morel, o mundo romano, de um modo geral, repetia as idéias de Platão e Aristóteles no que se refere à dicotomia entre conhecimentos liberais e práticos:

O corte essencial para os romanos não se situa entre as atividades intelectuais e atividades manuais, senão entre ocupações que tendem somente ao prazer do espírito e aquelas que são utilitárias, entre artes "liberais", dignas de um homem livre, como as matemáticas, a retórica ou a filosofia e todas as demais, desde os ofícios manuais até a medicina e a arquitetura. Mais de um romano teria podido tomar para si as opiniões de Platão e Aristóteles, segundo os quais os artesãos eram personagens vulgares e pouco nobres, indignos de serem considerados como cidadãos. Os técnicos mais hábeis não escapariam às críticas, desde o momento em que degradam as artes liberais com aplicações práticas. ${ }^{12}$

De acordo com Finley, o "divórcio claro, quase total, entre a ciência e a prática" era um aspecto intelectual característico do mundo antigo. "O objetivo da ciência antiga, tem sido dito, era saber, não fazer; entender a natureza, não domesticá-la". Para Aristóteles, apesar de sua ilimitada curiosidade, o interesse pelos conteúdos práticos e técnicos caracterizava um profundo mau gosto.

Os estudos e as ocupações, portanto, não deveriam satisfazer as necessidades humanas, a $\alpha v \alpha \gamma \kappa \eta$, mas a liberdade, as demandas do ócio e do prazer espiritual e moral. Esse era o juízo que orientava os critérios estabelecidos para a educação musical e para o julgamento da atividade do músico profissional. Aristóteles "exclui na educação ... toda disciplina que objetiva o exercício profissional: o homem livre deve visar à própria cultura". ${ }^{13}$ Estabelecia assim uma clara diferenciação entre fins práticos (ligados ao mundo do trabalho, da necessidade, do artesão, do meteco e do escravo) e fins teóricos (ligados ao ócio espiritual, à liberdade, ao aperfeiçoamento moral do cidadão). Assim, tanto para Platão como para Aristóteles, aprendia-se música não para o ofício (techné), mas para a educação (paidéia).

Como ficavam os conhecimentos e as ocupações musicais nesse esquema do divórcio entre a ciência e a técnica, entre as artes "liberais" e as atividades práticas? A música se situava junto à matemática, à retórica e à filosofia, como arte digna de um homem livre? Ou junto às demais artes e como os ofícios manuais, imprópria ao cidadão? A resposta é plural e aparentemente contraditória, pois dependia do tipo de vínculo que se tinha com a ocupação musical.

Um estudante de música, na juventude, deveria aprender, através das melodias, ritmos e harmonias corretamente escolhidos, as virtudes que deviam marcar o espírito do cidadão. Através da educação musical, os ritmos e harmonias se tornariam familiares 
às almas das crianças, de sorte que elas aprenderiam a ser mais gentis, harmoniosas e ritmadas; assim, tornar-se-iam mais aptas à palavra e à ação, pois a vida do homem, por toda parte, pensava-se, precisa de harmonia e ritmo. Enfim, o aprendizado da música tornaria as crianças mais civilizadas e daria modéstia à juventude. ${ }^{14}$ Nesse sentido, o estudo da música tinha um caráter "liberal".

No entanto, se mal conduzida, a educação musical poderia perder o seu caráter liberal. Assim, para não "amesquinhar o corpo ou inutilizá-lo para as ocupações marciais e cívicas do cidadão", "deve-se determinar até que ponto os alunos que estão sendo educados para a excelência na vida pública devem participar da educação musical". 15

O objetivo da educação musical, para Aristóteles, era, portanto, formar um amador, e nunca um profissional, haja vista serem os músicos profissionais considerados vulgares. ${ }^{16}$ Porquanto "os estudantes de música devem se abster de participar das competições profissionais e das maravilhosas exibições de virtuosismo ... incluídas em tais competições". Uma vez que o intuito é alimentar a alma com beleza moral, "eles devem praticar a música ... prescrita até o ponto em que estejam aptos a deleitar-se com as melodias e os ritmos mais belos". ${ }^{17}$ Devia-se estudar a música com vistas ao prazer dedicado à atividade intelectual, ${ }^{18}$ e nunca com o interesse técnico de tornar-se um instrumentista profissional.

Quanto ao estudo da teoria musical, enquanto ciência, sem interesses práticos, este era considerado digno do homem livre, pois levava ao aperfeiçoamento do espírito. Juntamente com a aritmética, a geometria e a astronomia, a música, como estudo teórico dos fenômenos musicais, era considerada uma ciência pura que treinaria o espírito para a elevação (epanagoghé) e conversão (anastrofé) do espírito, para atingir a disciplina suprema, a dialética ou a filosofia. ${ }^{19}$

No entanto, quando a dedicação à música implicava um caráter de servilidade, na medida em que esta fosse excessiva ou exercida como profissão, então não seria mais recomendada a um cidadão. A prática da música como profissão degradaria o espírito sob várias formas: por constituir uma atividade assalariada; pelo esforço manual e técnico necessário; por lembrar, de certa forma, a atmosfera dos vícios, prazeres frouxos e embriaguez; e, finalmente, pela pecha de efeminação da qual muitos músicos eram acusados. Essas condenações podiam recair sobre diferentes profissões musicais, desde o professor de canto ou lira e o concertista, até as "musicistas" (pornai e hetairai) e bailarinas que animavam os banquetes e os fabricantes de instrumentos. Poderemos 
entender os julgamentos negativos feitos sobre essas profissões se analisarmos por que lhes eram imputadas as condenações supra-referidas. Para tanto, passaremos à análise do estatuto do músico em relação ao mundo do trabalho.

\section{III - O Estatuto do músico em relação ao mundo do trabalho, do artesanato e da técnica:}

As formas como o imaginário grego conceituava o trabalho, o artesanato e a técnica, ligavam-se profundamente às noções antagônicas de liberdade e necessidade, $\varepsilon \lambda \varepsilon v \theta \varepsilon \rho ı \alpha$ e $\alpha v \alpha \gamma \kappa \eta$, e aos valores agregados a essas noções de que a dignidade e as honras $(\tau \imath \mu \alpha \imath)$ da cidadania só encontravam lugar quando o homem estivesse livre das necessidades da vida e, de forma inversa, de que ele seria marcado pela servilidade e brutalidade de espírito quando estivesse sempre na dependência da satisfação dessas necessidades. Para os filósofos, a liberdade não era somente uma condição jurídica significava estar liberto do jugo da sobrevivência e, assim, não precisar submeter-se aos outros para garantir seu sustento. Além disso, era somente nessa liberdade filosófica que se adquiria a virtude para o exercício da cidadania.

Assim, para Platão,

ser cidadão é um ofício que é a cultura da virtude: $\eta \tau \eta \varsigma \alpha \rho \varepsilon \tau \eta \varsigma \varepsilon \pi \imath \mu \varepsilon \lambda \varepsilon ı \alpha$; exclui qualquer outro .... Os cidadãos não poderiam de forma alguma ser artesãos. Os que infringissem a lei atrairiam o ultraje público (oneidos) ou a indignidade (atimia), ou seja, as sanções morais mais pesadas de que a cidade dispunha." 20

Platão, de um modo geral, inscrevia-se no lugar certo nessa grande corrente de pensamento grego que recusava qualquer carta de nobreza à atividade demiúrgica. Para ele, a demiurgia deteriorava o corpo, enquanto a banausia (o artesanato manual mais vulgar) e a kapéleia (o comércio varejista) deterioravam a alma.

Apesar de o artesanato ocupar um lugar capital na civilização grega - o que era por vezes reconhecido de forma bastante titubeante -, as invenções gregas por

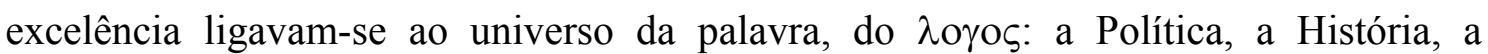
Filosofia, a Ciência, o Teatro, a Retórica. Essa civilização da palavra teve sempre dificuldade em conviver com o artesanato, com o trabalho e com a técnica, os quais foram relegados a um segundo plano. Parece que a célebre frase de Zilsel continua sendo a melhor síntese desse sistema de pensamento. Afirmava que, na Antigüidade, nur die Zunge, nicht die Hand als göttlich inspiriert. ${ }^{21}$ 
Parece igualmente ser verdade que os vencidos venceram os vencedores, pois averiguamos que os romanos são herdeiros, ou pelo menos partícipes, da ideologia do trabalho grega. Para Sêneca, as tarefas de um artesão são "vis" e "vulgares", e "nada têm que ver com as verdadeiras qualidades humanas". ${ }^{22}$ Do mesmo modo, para Cícero, “todo o artesão pratica um ofício vil". Pensava, da mesma forma, que "a oficina em nada é compatível com a condição do homem livre."23

Não bastando serem vis, vulgares e indignas do homem livre, recebem a balda do trabalho assalariado. Cícero afirmava que "todo salário é sórdido e indigno de um homem livre, pois constitui o preço do trabalho e não de uma arte". ${ }^{24} \mathrm{Um}$ dos fatores que condicionavam a indignidade das sórdidas artes do vulgo, pensava Sêneca, era que os trabalhadores braçais empregariam todo o seu tempo em ganhar a vida. Para ele, o trabalho assalariado nada tinha de belo e em nada se assemelhava ao Bem. ${ }^{25}$

Aristóteles afirmava que as atividades pelas quais se recebesse salário absorveriam e degradariam o espírito, pois não tinham como objetivo o seu benefício ou o de seus amigos. Quando se buscasse perceber um salário não se visariam às qualidades morais, pois, de forma mercenária e servil, agia-se submetido aos interesses de terceiros. Dessa forma, o trabalhador assalariado equiparava-se ao escravo, pois não era livre, uma vez que não trabalhava para si, mas para outrem. Do mesmo modo, cinco séculos mais tarde, o médico Galeano afirmava que um trabalhador assalariado, enquanto estivesse trabalhando, era um escravo, e só voltava a ser ele mesmo, separado do senhor, ao cair da noite.

Desse modo, quando se trabalhava por salário, não se detinha o uso do que se fazia - era escravidão. Assim, escravos e artesãos - da mesma forma que músicos profissionais - não podiam levar uma vida feliz, pois a liberdade era condição sine qua non da felicidade para Aristóteles. O músico, ao vender seu trabalho, participava da servilidade do artesão.

Podemos então entender as diferentes restrições ao trabalho do músico profissional, inserindo estas no contexto da repulsa ao artesanato e ao trabalho. $\mathrm{O}$ virtuose, ao tornar-se um especialista, acreditava-se, entrava no mundo da técnica e retirava-se do universo da liberdade. Adquiria "um aspecto corporal diferente por causa dos movimentos que eles têm de fazer". ${ }^{26}$ É por isso que, em suas utopias sociais, Aristóteles e Platão condenavam os instrumentos que exigiam do músico maior destreza manual. Platão, por exemplo, recomendava que fossem abandonados, nas "canções e 
melodias, instrumentos de muitas cordas, capazes de todas as harmonias" (Platão.

República, 399a). Aristóteles dizia que

muitos dos instrumentos mais antigos foram também condenados, como o péctis e o bárbitos e os instrumentos destinados a proporcionar apenas prazer a quem os ouvia tocados por outros por exemplo, o heptágono, o triângulo e a sambuca, e todos os que exigem grande habilidade $\underline{\text { manual. }^{27}}$

Com a exceção do bárbitos, esses instrumentos referidos por Platão e Aristóteles não compunham o repertório musical amador e diletante, apreciado por esses filósofos; este se constituía basicamente da lyra, do aulos (apesar da insistente censura a esse) e do canto monódico.

A recomendação para que o jovem não estudasse música com o objetivo de se tornar um profissional ligava-se ao temor de que esse fosse contaminado pela techné. Por isso, convinha controlar até que ponto os jovens deviam estudar música; ${ }^{28}$ por essa razão, rejeitava-se a profissionalização no ensino musical e na execução de instrumentos, ${ }^{29}$ por esse motivo, do mesmo modo, os adultos deviam afastar-se da execução musical; ${ }^{30}$ por isso, também, não era de bom tom que um jovem tocasse com muita habilidade, como se fosse um músico profissional. Assim compreendemos por que Filipe repreendeu seu filho, Alexandre (ainda menino), dizendo-lhe que devia ter vergonha de tocar com tanta habilidade, graça e talento, pois a um rei bastava ouvir o som da cítara e prestigiar concursos musicais, quando dispusesse de tempo, para prestar homenagem às Musas. ${ }^{31}$

Por sua vez, um músico, quando se sujeitava à percepção de um salário em troca de sua música, não se dedicava à arte das Musas em seu próprio benefício; não encontraria nela a beleza moral, pois o salário, de natureza sórdida, era incompatível com aquela. Ele estava, de forma subalterna, a serviço do prazer alheio. "Por isso não consideramos a execução condizente com um homem livre, mas extremamente subalterna". ${ }^{32}$ A participação em competições também era condenada, pois, como uma atividade profissional, não se participava das mesmas para o aperfeiçoamento próprio. ${ }^{33}$ A música, praticada para se receber um salário, como forma de garantir o sustento, adquiria caráter vulgar, degradador do espírito. ${ }^{34}$ Pouco importava se o salário correspondesse a míseros 2 dracmas por noite (remuneração das jovens "artistas" alugadas a seus proxenetas, conforme a legislação vigente em Atenas) ${ }^{35}$ ou à respeitável soma de 700 dracmas anuais percebida por um professor de música em Teos no séc. II a.C. ${ }^{36}$ Era sempre uma espécie de homem de ofícios, um $\beta \alpha v \alpha v \sigma o \varsigma$, mesmo quando 
conseguisse acumular uma vultosa fortuna, como foi o caso do auletes Ismênias, considerado uma nulidade pelo cínico Antístenes, nada obstante possuísse riqueza suficiente para dispor de 7 talentos (42 mil dracmas) para encomendar um sofisticadíssimo instrumento. Ora, uma riqueza acumulada através de salários era sempre uma riqueza que levava o estigma da submissão, da servilidade.

Assim, as confusas representações coletivas sobre o trabalho não poupavam o músico, apesar de toda estima que se tinha pela música. Nem sequer o professor, cujo papel social era inestimável, escapava desses julgamentos, que, no caso, tornavam-se, às vezes, bastante confusos, pois era inevitável reconhecer-se o valor de seu trabalho profissional.

As opiniões sobre o professor de música comportavam-se de forma ambígua, ora admirando seu saber liberal e a sua responsabilidade por introduzir o filho no culto às Musas, ora desprezando sua servilidade, sua dependência do salário para seu sustento. Essa ambigüidade, essa divergência de opiniões, leva-nos a formular duas questões correlatas acerca da imagem do músico:

Primeira: O que pensavam sobre si mesmos os músicos? Essa pergunta, referente à auto-imagem do músico, a seu orgulho próprio, tendo sido tratada em nossa pesquisa, não será aqui abordada, uma vez que este artigo tem como tema a imagem pública do músico.

Segunda: Essas opiniões preconceituosas sobre os músicos profissionais eram compartilhadas por todos os extratos sociais? Perguntando de outra forma, preocupavam-se todos com esses julgamentos filosóficos e esses postulados da "ideologia do trabalho manual" e da "ideologia da causa final"?

Sobre essa última questão, é necessário dizer que esses conceitos ligavam-se a um imaginário social originado nas elites econômicas e políticas terratenentes, que se manteve válido como forma de avaliar as atividades profissionais mesmo em contextos históricos posteriores, nos quais as elites políticas e econômicas já tinham adquirido um perfil mais complexo. No entanto, o fato de ser uma idéia sustentada pelas elites gregas e romanas - e defendida com afinco pela inteligentsia que a representava - não significa que fosse compartilhada por todos. Em verdade, na opinião popular moderna sobre a Antigüidade, como dizia E. Meyer, produziu-se "uma imagem fantástica da teoria do desapreço do trabalho manual", ${ }^{37}$ que resultou num julgamento histórico equivocado, pois levou à conclusão de que fosse um ponto de vista apoiado irrestritamente por toda sociedade. Mesmo que o registro histórico tenha deixado menos vestígios dos 
pensamentos que divergiam da "ideologia do trabalho manual", da "ideologia da causa final" e da teoria demiúrgica, muitos pensaram de outra forma.

Conforme Salvioli, essa ideologia mantinha uma relação estreita com o ideal agrário que perfilava o modelo da cidadania na Roma republicana. ${ }^{38}$ Esse ideal agrário, porém, não era compartilhado por todos. A predominância dos textos que priorizavam o agricultor, bem como o guerreiro, em relação ao artesão, provoca, na expressão de Vidal-Naquet, uma "ilusão de ótica" na interpretação historiográfica moderna - a ilusão de que essa seria a única perspectiva. No entanto, um olhar mais atento descobrirá uma corrente de pensamento paralela - talvez uma "visão do dominado" - que valorizava o artesão e seus saberes. Essa perspectiva já encontrava guarida nos antigos mitos. Platão lembrava que a Hefesto e Atena era "consagrada a raça dos artesãos cujos ofícios conjugados organizaram a vida" em cidade. ${ }^{39}$

Podemos antever, então, uma ambigüidade no estatuto do artesão, cujo testemunho mais luminoso se encontra na obra de Platão, em que dois sistemas de valores se confrontam. Em paralelo ao sistema público oficial, que prioriza o geórgos (agricultor), encontramos, no Timeu e nas Leis, um sistema dissimulado, que privilegia o démiourgos (artesão). Platão reconheceu, na função artesanal (de Prometeu e Hefesto), o centro da atividade humana. Interessa-nos que, nessa valorização da demiurgia, escondia-se uma corrente de pensamento que não guardava preconceitos tão marcantes quanto ao trabalho assalariado. Platão soube enaltecer o personagem do artesão, ao colocar o Demiourgos, um artesão, como criador do mundo. ${ }^{40}$

A valorização do mundo do trabalho, do artesanato, das profissões (entre as quais pode incluir-se a de músico), estava elaborada no conceito de Métis, uma categoria mental quase esquecida, que perpassou a cultura grega. Em seu estudo sobre esta, Detienne e Vernant definem-na como a "malícia da inteligência". Trata-se tanto da habilidade do artesão, do oleiro ou tecelão, como da capacidade quase animal do caçador, do pescador ou mesmo do jovem soldado que participa de uma emboscada. Métis é tanto o manuseio hábil e preciso dos materiais pelo fabricante de instrumento para construí-los, como a destreza das mãos do citarista ou auletés, como a delicadeza do canto do músico. Um virtuose, como o auletes Ismênias ou o citarista Lisandro, notabilizaram-se pela sua métis musical. Métis é uma astúcia conjugada entre as mãos e a inteligência. Podemos dizer que, para essa corrente de pensamento, não vale a conclusão de Zilsel, de que entre os antigos a língua, e não a mão, era inspirada pelos deuses. Parece-nos que aqueles que sabiam valorizar a métis não repetiriam com tanto 
aferro a "ideologia da causa final", como o faziam os filósofos. Para aqueles, é como se a causa final e a motriz fossem de igual importância. $\mathrm{O}$ que pensariam essas vozes silenciadas pela historiografia sobre a causa motriz da música, o músico?

A mesma fonte que nos revela a censura do filósofo Antístenes ao flautista Ismênias revela também a existência de alguém que, pouco interessado nos julgamentos filosóficos, bastava-se em admirar as qualidades técnicas do célebre virtuose tebano. Como podemos ver nesse curto trecho de Plutarco, já citado anteriormente: "Bastante razão teve Antístenes quando respondeu a alguém que lhe afirmava ser Ismênias um excelente flautista: 'Sim, mas como homem é uma nulidade, do contrário não tocaria tão bem'. "41

Como podemos concluir, as reprimendas de cunho filosófico sobre o virtuosismo de Ismênias - partilhadas por Plutarco - em nada prejudicaram sua fama e seu enriquecimento. Bastante admirada foi a métis de vários outros músicos, sobre os quais as fontes nos fornecem inúmeros exemplos. É o caso da admiração pelo citarista Lisandro (séc. VI), citado por Ateneus, cuja técnica, inspiração e destreza lhe permitiram fazer da cítara um instrumento colorido, tocando-a como um aulos. Tocá-la "como um aulos" significava que sua métis musical era tão sofisticada que, mesmo com uma cítara, conseguia descrever uma narrativa. Tal era sua capacidade de obter timbres e efeitos inesperados, que os sofistas - personagens do diálogo de Ateneus - dão a entender que ele tocava a cítara como se fosse vários instrumentos. ${ }^{42}$

Os espectadores das competições musicais deviam pensar do mesmo modo que os admiradores de Ismênias e Lisandro. Inúmeras evidências apontam que muitos músicos profissionais foram louvados por seus contemporâneos, apesar de todos os preconceitos em relação à profissão. Era comum que alguns alçassem à fama, como esses dois notáveis instrumentistas, cuja destreza e arte foram celebradas ao longo da Antigüidade. A lista de músicos que atingiram o reconhecimento e a glória é, na verdade, bastante extensa, contando inclusive com seus contrapontos lendários, como o músico tebano Arion, que, segundo a narrativa mítica, teria feito fortuna na Sicília graças ao seu talento musical. A fama, riqueza e genialidade de um auletes como o tebano Pronomos ou o citarista e professor ateniense Estratonicos são exemplos desta proeminência social e econômica que alguns músicos adquirem em virtude de seu notável talento. Muitos virtuosi enriqueceram, da mesma forma que Ismênias. Tendo em vista elevada estima com que os gregos guardavam a música, supõe-se que era 
bastante comum valorizar um músico talentoso e até mesmo adular o vencedor em algum concurso.

A remuneração superior do professor de música em relação aos de letras e ginástica traduz, com certeza, uma valorização profissional. $\mathrm{Na}$ fundação escolar de Polítrous, que fixou o ensino público em Teos no séc. II a.C., foram contratados três professores de letras, dois de ginástica e um único de música. ${ }^{43}$ Um dos motivos dessa diferença - inaceitável na época clássica - é que no período helenístico os músicos tornaram-se profissionais muito caros, devido à crescente especialização técnica, de modo que o professor de música percebia um salário de 700 dracmas anuais, enquanto os outros receberiam, no máximo, 600 .

A partir da época de Alexandre, assiste-se, em algumas regiões da Grécia, à formação de corporações de músicos, as quais, graças ao efeito de seu esprit de corps, garantiam honorários elevados para a profissão. Em Mileto, havia um colégio de músicos, os Molpoi. Assim, na época helenística, os coros não eram mais entregues a amadores recrutados entre os cidadãos, mas a grupos de artistas profissionais, os $\tau \varepsilon \chi \vee \imath \tau \alpha 1$. A tendência foi a substituição de coros amadores por coros profisssionais, bem como a atribuição da função de professor a profissionais muito qualificados e bemremunerados. Porém, por motivos de economia, em sendo os honorários desses $\tau \varepsilon \chi \vee \imath \tau \alpha$ เmuito custosos, a substituição não foi total, ${ }^{44}$ e continuaremos a ver, segundo os registros, coros amadores nas cidades gregas até um período avançado da idade imperial.

Esse processo de valorização do músico profissional pode ser atestado pela prosopografia de alguns músicos, a qual revela uma espécie de processo de sindicalização. As escavações de Delfos nos revelam dados da história de dois músicos, Elpinikios e Cléon, que não eram propriamente professores, mas artistas líricos. Nas Píticas $^{45}$ de 138-137 a.C., a cidade de Atenas enviou a Delfos um coro de amadores, tendo como khorodidaskaloí contratados Elpinikios e Cléon. ${ }^{46}$ Uma década mais tarde, os mesmos músicos estarão representando Atenas nas celebrações em Delfos. No entanto, agora participam como membros do

coro de trinta e nove profissionais, ${ }^{47}$ fazendo parte da numerosa troupe de $\tau \varepsilon \chi \nu \imath \tau \alpha \iota$ atenienses (são uns sessenta ao todo) que acompanham dessa vez a delegação e cuja brilhante participação na cerimônia lhes valeu o reconhecimento da população de Delfos. ${ }^{48}$ 
Elpinikios e Cléon atestam um avanço no reconhecimento do trabalho profissional do músico, ao testemunharem a adesão pelos atenienses ao emprego desses $\tau \varepsilon \chi \nu \imath \tau \alpha \imath$ musicais na representação da cidade em Delfos. Significa também que a comunidade concordava em onerar os cofres públicos com a dispendiosa remuneração dos músicos. Mesmo que vistos como torpes por filósofos e membros da elite, não se negava o reconhecimento de suas qualidades na arte das Musas. O próprio Aristóteles, defensor da música amadora, precisou curvar-se diante do fato de que os músicos profissionais eram superiores $^{49}$ na execução da arte patroneada por Apolo.

Assim, quanto à opinião acerca do músico como profissional, é possível também que ocorra uma certa "ilusão de ótica". Não obstante o preconceito que a ideologia dominante depositava sobre o músico profissional, muitos serão aqueles que saberão respeitar e admirar a dignidade e o talento dos virtuosi.

\section{IV - Conclusão:}

Se, em alguns casos, podia ser encontrada uma certa dignidade, como na ocupação de professor, avaliada por muitos como uma atividade liberal, a condição de trabalho assalariado era sempre suficiente para a acusação de servilidade. À pecha da dependência de uma remuneração, somavam-se a balda do esforço físico deformante, próprio da técnica (o caso dos concertistas) e o estigma da indecência de profissões que sobreviviam dos submundos e dos prazeres banais (situação das hetairai e pornai do mesmo modo como de alguns cantores, atores e citaristas que, como mulheres, submetiam-se ao desejo sexual homoerótico de outros homens). Não faltariam paralelos mitológicos para sustentar essas visões preconceituosas com relação ao músico: a efeminação de Orfeu; a fragilidade de Anfion em oposição à virilidade guerreira de seu irmão gêmeo Zetos; a rejeição do valentão Héracles às aulas de música de Linos; ou a hybris (desmedida) do citarista Tamyras ou do sileno flautista Mársias, que ousaram desafiar respectivamente as Musas e seu mestre, Apolo.

Pensava-se que um músico amador, que fosse comedido no seu envolvimento com a música, evitando instrumentos de difícil execução e afastando-se das competições, prestava homenagem às Musas sem ofender a virilidade e as honras do cidadão. Educava, pois, seu caráter na audição de melodias compostas nos modos dóricos e lídios, portadoras do ethos praktikós e ethos ethikós. Do mesmo modo, aqueles que se dedicavam à teoria musical não eram vistos como homens vulgares; 
contudo, eram, em sua grande maioria, professores que cobravam para ensinar seus conhecimentos, o que seria motivo suficiente para repreensões por parte daqueles que desprezavam o salário. Achava-se que, diferentemente dos músicos que serviam a fugazes e condenáveis prazeres, esses espíritos iluminados que se dedicavam à teoria musical alcançavam uma purificação da alma, enchendo-a de alegria, pois a ciência musical, a $\mu о v \sigma \iota \kappa \eta$, participava do prestígio da astronomia, pela qual a alma entrava em comunhão com os deuses estelares, tornando-a divina ao separá-la das baixezas terrestres.

Como vemos, a valorização filosófica, pedagógica, espiritual e religiosa, da qual se revestiu a música entre os gregos desde os tempos homéricos, não emprestou sua importância àqueles que se empenharam, como profissionais, a prestigiar a arte das Musas. Todavia, houve sempre uma certa ambigüidade. Mesmo prevalecendo o julgamento de que fossem pessoas suspeitas, muitos desprezavam essas retaliações e preferiam reconhecer os méritos dos renomados concertistas e professores que sabiam engrandecer essa arte cuja linguagem era tão apreciada pelos gregos. Indiferente às censuras filosóficas e moralistas, o público que acorria às competições musicais aplaudia efusivamente os vencedores pela sua destreza técnica e inspiração. É assim que o flautista Timóteo, de Tebas, tornou-se célebre pela sua interpretação da peça $A$ loucura de Ajax, de Timóteo, o Milésio. O reconhecimento social de compositores devia ocorrer de forma análoga: assim, a qualidade das composições de Mesomedes de Creta foi coroada com sua nomeação como músico oficial da corte de Adriano, semelhante ao que ocorreu, dezesseis séculos mais tarde, com Mozart na época dos Habsburg.

Destarte, a auto-estima de músicos sérios, que dedicavam horas de estudo a seus instrumentos, não se deixava abalar diante das reprimendas daqueles que os queriam comparar com prostitutas e rapazes "afrescalhados". A certeza de estarem cultuando as Musas garantia o orgulho de seu métier, além de sustentar a crença de que suas almas usufruiriam de privilégios após a morte, graças à proteção que estas lhes proporcionariam. Podiam sempre lembrar aos homens cultos que, segundo os pitagóricos, a ordem do mundo fundada sobre o rigor do número era uma harmonia, uma música. Diante das censuras que lhes eram feitas, podiam sempre retorquir que a música humana, das vozes e instrumentos, que encontrava sua melhor expressão no trabalho de citaristas, liristas, auletai e citaredos profissionais, participava da música das esferas. Numa passagem do Sonho de Cipião, Cícero, revelando-nos certa influência neopitagórica, valoriza o papel espiritual dos músicos: 
Os doutos espíritos que souberam imitar essa harmonia com a lira e o canto traçaram o retorno ao céu (o céu, morada dos Bem-aventurados), da mesma forma que os possantes gênios que, ao longo da vida mortal, cultivaram as ciências divinas. ${ }^{50}$

Marrou caracteriza bem essa atitude ambivalente diante dos músicos profissionais:

Eles são, com certeza, admirados por seu talento, e não se hesitará jamais em pagar seus serviços por bons preços, mas ao mesmo tempo são desdenhados: não pertencem normalmente ao meio social onde são recrutadas as pessoas cultas; seus hábitos, sem dúvida, não são tão suspeitos como aqueles dos pantomimos; no entanto o caráter mercantil de sua atividade basta para lhes desqualificar: são gente de ofício, banausoi. ${ }^{51}$

Para conseguirmos compreender esse cluster de opiniões sobre o músico, às vezes bastante coerente, mas em alguns momentos tão contraditório, devemos recorrer a Veyne, que nos lembra que as idéias quanto ao trabalho não eram doutrinas, obras de pensadores e juristas,

mas confusas representações coletivas que eram também representações de classe ... Tais representações visavam globalmente a grupos sociais inferiores, reduzidos a viver de salário ou a se colocar a serviço de alguém. Não pretendiam organizar a conduta de todos segundo as regras, e sim exaltar ou enaltecer uma classe social onde tudo é mais ou menos verdadeiro. ... Todos são acusados de trabalhar. ... As idéias antigas sobre o trabalho eram menos idéias do que valorizações, positivas para os poderosos e negativas para os humildes. ${ }^{52}$

À guisa de conclusão, nesse conjunto de julgamentos sobre o músico, "tudo é mais ou menos verdadeiro", sendo um equívoco perguntar-se o que realmente pensavam. Causava espécie que pessoas tão pouco respeitosas como prostitutas e artistas mambembes fossem coroadas com a arte das Musas. Já professores responsáveis pela formação dos filhos de homens bem nascidos - e concertistas - que circulavam em meios sociais de maior projeção - não são de todo pessoas maltrapilhas e suspeitas, podendo aspirar, juntamente aos poetas, a dignidade de verdadeiros obtentores dos favores das Musas para o conforto dos homens; porém, estão reduzidos a viver de salário ou a se colocar a serviço de alguém. A dignidade liberal de um professor de lira, canto ou teoria ofuscava-se diante da imagem de ser homem pobre. ${ }^{53}$ O mesmo ocorria em relação ao virtuose. Não obstante o reconhecimento de seus talentos, Aristóteles considerava a execução extremamente subalterna, pois

os executantes se tornam vulgares, uma vez que seu escopo é mau, já que a vulgaridade da audiência geralmente influencia a música, de tal forma que ela dá aos artistas que a executam com o fito de ser agradáveis à audiência um caráter peculiar, e também um aspecto corporal diferente por causa dos movimentos que eles têm de fazer.

Vemos, no pervicaz desdém aristotélico atinente ao solista, a obstinação em diminuir os méritos daquele artista que se auto-representava como leal e tenaz profeta das Musas. 
Finalmente: desprezo ou admiração? Ambos, dependendo de quem emite a opinião e em que situação a pronuncia.

CERQUEIRA, Fábio Vergara The Public Image of the Musician and the Music in Classical Antiquity: Despise or Admiration? História, São Paulo, v. 26, n. 1, p 63-81, 2007.

Abstract: The object of this article is to analyse the representations set that defines the musician in the social imaginary of the ancient Greek and Roman societies. The objective is to rebuild the public image that men of Classical Antiquity had created in relation to the musicians. Such image was composed of a cluster, rather coherent and contradictory, of notions, concepts, beliefs and preconceived ideas.

Keywords: Classic Antiquity, Greek-Roman musician, Public image.

Artigo recebido em 04/2007. Aprovado em 06/2007.

\section{NOTAS}

\footnotetext{
* Professor de História Antiga do Departamento de História e Antropologia - Instituto de Ciências Humanas - UFPEL - 96010770 - Pelotas/RS. E-mail: fabiovergara@uol.com.br

${ }^{1}$ Filósofo grego, Antístenes (444-365) foi discípulo de Sócrates, fundador da escola cínica e mestre de Diógenes.

2 "Ismênias de Tebas, um dos auleutas mais ricos e mais prestigiados da Antigüidade, encomendou, de um atelier de Corinto, um instrumento que ele comprou por 7 talentos (isto é, 42.000 dracmas; comparativamente, um trompete valia somente 60 dracmas". (BÉLIS, Annie. Les instruments de la Grèce Antique: des vestiges et la reconstituition. In: La musique dans l’Antiquité, Les Dossiers d'Archeologie, 1989,. p.45.)

${ }^{3}$ Trata-se de Filipe II, rei da Macedônia. O filho, no caso, é Alexandre, o Grande.

${ }^{4}$ Plutarco. Péricles, 1.

${ }^{5}$ VERNANT, Jean-Pierre. Aspectos psicológicos do trabalho na Grécia antiga. In: VERNANT, J.-P. \& VIDAL-NAQUET, P. Trabalho e Escravidão na Grécia antiga. Campinas: Papyrus, 1989. p.36.

${ }^{6}$ Idem., p.41.

${ }^{7}$ MOREL, Jean Paul. El artesano. In: GIARDINA, Andrea (et alli). El hombre romano. Madrid: Alianza Editorial, 1991. p.264.

8 MOUTSOPOULOS, Evangelos. La musique dans l'oeuvre de Platon. Presses Universitaires de France, 1959. p.92-96.

${ }^{9}$ Platão. Fédon, 61a. Sócrates, pouco antes de sua morte, interpretou um sonho que tivera de que devia praticar a arte musical, o que o leva a compor e musicar um hino ao deus Apolo.

${ }^{10}$ Plutarco. Temístocles, 2.

${ }^{11}$ Idem.

12 MOREL, Jean Paul. Op. cit., p.261.

${ }^{13}$ MANACORDA, M. A. História da Educação da Antigüidade aos nossos dias. São Paulo: Cortez, 1989. p.57.

${ }^{14}$ Platão. Protágoras, 323-327; República, 399sq.

${ }^{15}$ Aristóteles. Política, VIII, VI, 1341a,b.

${ }^{16}$ Idem, VIII, IV, 1339b.

${ }^{17}$ Idem.

${ }^{18}$ Idem, VIII, IV, 1338a.
} 
${ }^{19}$ MANACORDA, M. A. Op. cit.

${ }^{20}$ VIDAL-NAQUET, Pierre. Estudo de uma ambigüidade: os artesãos na cidade platônica. In: VERNANT, J.-P. \& VIDAL-NAQUET, P. Op. cit., p.150.

21 "Somente a língua, e não a mão era inspirada pelos deuses." (E. Zilsel, Geniebegriff, p.27.)

${ }^{22}$ MOREL, Jean Paul. Op. cit., p. 259.

${ }^{23}$ Idem.

${ }^{24}$ VEYNE, Paul. Trabalho e Ócio. In: História da Vida Privada - Do Império Romano ao ano mil I. São Paulo: Cia. das Letras, 1991,.p.126.

${ }^{25}$ Idem.

${ }^{26}$ Aristóteles. Política, VIII, VII, 1342a

${ }^{27}$ Idem, VIII, VI, 1341b. Destaque em sublinhado do autor.

${ }^{28}$ Idem, VIII, VI, $1341 \mathrm{a}$.

${ }^{29}$ Idem, VIII, VI, 1341b.

${ }^{30}$ Idem., VIII, VI, 1341a.

${ }^{31}$ Plutarco. Péricles, 1.

${ }^{32}$ Aristóteles. Política, VIII, VII, 1342a

${ }^{33}$ Idem, VIII, VI, $1341 \mathrm{~b}$.

${ }^{34}$ Idem, VIII, II, $1337 \mathrm{~b}$.

${ }^{35}$ SALLES, Catherine. Nos submundos da Antigüidade. São Paulo: Brasiliense, 1987,. p.102.

${ }^{36}$ MARROU, H. I. Histoire de l'éducation dans l'Antiquité. Paris: Éditions du Seuil, 1981. p.206.

37 MEYER, E. L"evoluzione Economica dell'Antichità. in: PARETO, V. Biblioteca di Storia

Economica, Milão: SEL, 1905. p.6. "Non solo l'opinione popolare si è fatta un'immagine fantastica della teoria del lavoro manuale, del tipo del citadino alimentato del lavoro di altri, che può vivere solo dello Stato, e inoltre di una vita spirituale, raffinata e artistica, degli aneddoti della demoralizzazione dell'epoca imperiale, degli schieri di schiavi de' signori romani, e che, secondo il bisogno, ora può essere lodata come l'ideale più alto, come tipo per la corrota vità politica del presente, ora non può essere dipinta abbastanza in nero come demoralizzata, e quinde costituisce una comoda follìa per il Cristianesimo. Anche ne' circoli scientifici sono altamente diffusi simili concetti; s'incontrano non solo presso gli economisti, ma anche presso gli storicci ".

${ }^{38}$ SALVIOLI, Giuseppe. Il capitalismo, cap.VIII. In: Il capitalismo antico. Bari: Laterza, 1984, p.169.

${ }^{39}$ VIDAL-NAQUET, Pierre. Op. cit., p.170.

${ }^{40}$ Idem.

${ }^{41}$ Plutarco. Péricles, 1. Destaque em sublinhado do autor.

${ }^{42}$ BARKER, Andrew. The innovation of Lysander the kitharist. Classical Quarterly, XXXVII, 2, 1982, 266-9. Segundo Barker, as fontes sobre Lisandro causaram confusão na interpretação, sobretudo a referência feita em Ateneus, 637-8. Já se interpretou uma passagem como se ele tocasse vários instrumentos, ou como se alternasse a cítara e o aulos, ou como se tocasse a cítara soando como aulos, o que seria impossível.

${ }^{43}$ Ditt. Syll. 578, 9; $13 ; 15$.

${ }^{44}$ MARROU, H. I. Op. cit., p.389, nota 11 do cap.IV: "L'inscription F. Eph., II, n. 21, 1. 53 s., nous apprend comment, en 44 après Jésus-Christ, sur l'intervention du proconsul Paullus Fabius Persicus, les hymnodes professionnels jusque-là en service durent être remplacés par un choeur d'ephèbes. Le motif invoqué est une raison d'économie (l'entretien de ce choeur aurait absorbé la plus grande partie des revenus de la cité!), mais il n'est pas exclu que la mésure ait eu une arrière-pensée politique."

${ }^{45}$ Durante as festividades, realizadas em Delfos para comemorar a vitória de Apolo sobre o monstro Píton, nos meses de setembro e outubro de terceiro ano após a realização dos jogos Olímpicos, ocorriam os jogos Píticos. Nessa competição, predominavam as disputas musicais, com a kithára, talvez como

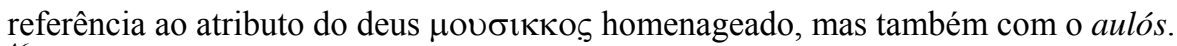

${ }^{46}$ F. Delph. III, 2, 11, 20-22.

${ }^{47}$ F. Delph. III, 2, 47, 9-14.

${ }^{48}$ MARROU, H. I. Op. cit., p.205. "On sait que nous pouvons juger, sur pièces, de l'intérêt de leur contribuition, puisque nous avons retrouvé, gravés sur les murs du trésor des Athéniens, le texte littéraire et musical de deux des hymnes à Apollon qui furent chanté à cette occasion."

${ }^{49}$ Aristóteles. Política, VIII, IV, 1339b.

${ }^{50}$ Cícero. De Republica, 5, 18. A mesma doutrina é retomada em Jâmblico. Vida de Pitágoras, 66-67.

${ }^{51}$ MARROU, H. I. Op. cit., p. 212.

${ }^{52}$ VEYNE, Paul. Op. cit., p.127-8. Destaque em sublinhado do autor.

${ }^{53}$ Idem, p.130-1. 